УДК: 331.5

Битов В.П., к.е.н., доцент

Горбач Л.М.,, к.е.н., доцент

Волинський інститут ім. .Липинського МАУП

\title{
МІСЦЕ І РОЛЬ ПІДПРИЕМНИЦТВА ЯК СУСПІЛЬНОГО ЯВИЩА В УМОВАХ РИНКУ
}

\begin{abstract}
У публікації розглянуто роль і значення підприємництва для сучасного стану української економіки, яка дає змогу суб'єктам підприємницької діяльності формувати самостійну, ініціативну діяльність 3 виробництва товарів та надання послуг з метою одержання прибутку. Розглянуто розробку теорії підприємництва, а також основні мотиви підприємницької діяльності. У даній публікації виділено основні напрямки підприємницької діяльності, які передбачають здійснення нововведень при використанні власних коштів, а також самостійність у прийняті рішень і ризик. Розглянуто також в залежності від змісту діяльності види підприємництва. Запропоновано окремі механізми щодо можливості ефективного розвитку підприємництва, як надважливого складового елементу розвитку ринку, а також соціальну та економічну значимість підприємництва для суспільства.
\end{abstract}

Ключові слова: підприємництво. підприємець, ринкова економіка, прибуток, кошти, ресурси, підприємницький ризик, бізнес, менеджмент.

Bitov V., Gorbach L.

\section{THE PLACE AND ROLE OF ENTREPRENEURSHIP AS A SOCIAL PHENOMENON IN A MARKET ENVIRONMENT}

The publication examines the role and significance of entrepreneurship for the current state of the Ukrainian economy, which enables business entities to form independent, initiative activities in the production of goods and provision of services in order to profit.

The article deals with the development of the theory of entrepreneurship, as well as the main motives of entrepreneurial activity. This publication highlights the main areas of entrepreneurial activity, which involves making innovations using own funds, as well as autonomy in decision making and risk. Considered also depending on the content of the activities of the business. Some mechanisms are proposed concerning the possibility of effective development of entrepreneurship, as an extremely important component of market development.

Key words: entrepreneurship. entrepreneur, market economy, profit, funds, resources, business risk, business, management.

Бытов В.П., Горбач Л.Н.

\section{МЕСТО И РОЛЬ ПРЕДПРИНИМАТЕЛЬСТВА КАК ОБЩЕСТВЕННОГО ЯВЛЕНИЯ В УСЛОВИЯХ РЫНКА}

В публикации рассмотрены роль и значение предпринимательства для современного состояния украинской экономики, что позволяет субъектам предпринимательской деятельности формировать самостоятельную, инициативную деятельность по производству товаров и услуг с целью получения прибыли. Рассмотрены разработку теории предпринимательства, а также основные мотивы предпринимательской деятельности. В данной публикации выделены основные направления предпринимательской деятельности, В данной публикации выделены основные направления предпринимательской деятельности, предусматривает осуществление нововведений при использовании собственных средств, а также самостоятельность в принятии решений и риск. Рассмотрены также в зависимости от содержания деятельности виды предпринимательства. Предложено отдельные механизмы по возможности эффективного развития предпринимательства, как важнейшего составного элемента развития рынка.

Ключевые слова: предпринимательство. предприниматель, рыночная экономика, прибыль, средства, ресурсы, предпринимательский риск, бизнес, менеджмент.

Постановка проблеми у загальному вигляді та їі зв'язок 3 важливими науковими і практичними завданнями. Підприємництво це самостійний суб'єкт господарювання, який має право юридичної особи і здійснює свою діяльність, яка не 
заборонена чинним законодавством на свій розум, страх і ризик. Підприємницька діяльність це необмежене поле прикладання своїх зусиль. Вона різноманітна, як i різноманітні людські потреби. Сьогодення вимагає все більшого кола випуску продукції i надання послуг, а цього можна досягти завдяки розвинутому підприємництву. Дослідники і науковці вивчаючи питання підприємництва говорять про те, що однією 3 проблем сучасної економіки України - це нестача людей, здатних і відповідним чином підготовлених до підприємницької діяльності. Бажаючих до підприємницької діяльності в період перших років незалежності України було багато, проте лише одиниці стали справжніми та успішними підприємцями. Адже сучасний ринок вимагає щоб сучасний підприємець був високоосвіченою людиною, орієнтуватися в складних ситуаціях економіки, досконало знати виробництво, володіти необхідною інформацією, дотримуватися норм високої моралі та етики в своїй діяльності.

Аналіз останніх досліджень і публікацій, у яких започатковано вирішення проблеми. Щодо аналізу останніх досліджень і публікацій то слід відмітити, що підприємництво як активний елемент бізнесу здавна привертає увагу дослідників. Зокрема у роботах, І.А. Бланка, А. Сміта, Й. Шумпетера підприємництво розглядається як у загальнотеоретичному, так і в практично-функціональному плані. Значний вклад по вивченню питань щодо формування підприємницького середовища, участь підприємництва у державних і регіональних програмах, а також впливу держави на формування підприємництва у виробничій сфері, вивчення питання теорії та історії підприємництва в Україні вносять сучасні автори - Вербова О.С. Чуткий А.І., Небрат B.В., Горін Н.О., К. Ляпіна та ін. Однак наукові суперечки щодо змісту поняття «підприємництво», його сутності не можна вважати в повному обсязі опрацьованими. Адже у визначені підприємництва підкреслюється один незаперечний факт, який свідчить про те, що підприємець діє з метою привласнення прибутку. Вивчення даного питання схиляє нас до думки, а яка суспільна корисність від підприємницької діяльності. Вбачаємо, що не до кінця дослідженими залишаються напрями розвитку соціального підприємництва, шляхи їх залучення до соціального розвитку держави та регіонів. Адже ринкова економіка, стимулюючи розвиток підприємницької діяльності, створює умови для узгодження приватних і суспільних інтересів. А звідси вбачається, що необхідною рисою сучасного підприємництва $€$ його участь у розв'язанні соціальних і економічних проблем суспільства.

Цілі статті. Мета статті полягає у розкритті сутності та визначенні підприємництва, а також його значення і роль в сучасному ринку. Відображення у даній публікації існуючих типів і форм підприємницької діяльності, що діють в сучасній економіці. Показати зв'язок сучасного підприємництва у розв'язанні соціальних i економічних проблем суспільства.

Виклад основного матеріалу дослідження 3 повним обгрунтуванням отриманих наукових результатів. Підприємництвом називають самостійну, ініціативну діяльність 3 виробництва товарів та надання послуг 3 метою одержання прибутку. Підприємець - це самостійний агент ринку, котрий діє на свій страх і ризик, під особисту відповідальність за результати бізнесової діяльності. Таке розуміння підприємництва сформувалося не відразу. Різні дослідники протягом двох століть робили свої внески у визначення того, що $є$ підприємництвом. Серед них Рене Кантільон, Макс Вебер, Вернер Зомбарт, Йозеф Шумпетер.[2.c.161]. Підприємництво є категорією бізнесу. У господарській практиці категорії «підприємництво» і «бізнес» часто ототожнюють. Водночас це нетотожні, хоча й дуже близькі за значенням поняття. Згідно із словником Даля, «Бізнес - це справа, або будь-який вид людської діяльності, 3 метою отримання прибутку». Отже, бізнес - поняття ширше, ніж підприємництво i охоплює всі відносини, що виникають між усіма учасниками ринкової економіки: підприємцями, споживачами, найманими працівниками та державою. Основним теоретиком підприємництва і бізнесу вважають французького банкіра - економіста Р. 
Кантільйона, який ще на початку XVIII ст. ввів поняття «підприємництво». Особливу роль також у розробленні теорії підприємництва відіграв німецький соціолог М. Вебер. У його наукових працях відтворено ідеальний тип підприємця 3 яскраво вираженими етичними якостями. Теоретичні розробки цих і багатьох інших західних економістів $\epsilon$ основою сучасних концепцій підприємництва. [10.с.35].

На сьогодні законодавство України про підприємництво визначає загальні правові, економічні та соціальні засади здійснення підприємницької діяльності фізичними і юридичними особами на території України, гарантії свободи підприємництва та його державної підтримки. Звідси підприємницька діяльність - це діяльність ініціативних, енергійних, творчих, кмітливих, цілеспрямованих, порядних людей, які реалізують важливі, складні, сміливі ідеї та рішення, беруть на себе ризик, що пов'язаний 3 реалізацією їх. Таким чином, підприємницька діяльність $є$ поняттям багатогранним, що втілює у собі інтелектуальні здібності, потрібні в управлінні, менеджменті, бізнесі, комерційній діяльності, технології виробництва товарної продукції на рівні різних інститутів багатоукладної інфраструктури ринку.

В Україні підприємництво здійснюється за такими принципами:

- вільний вибір виду діяльності;

- залучення на добровільних засадах для здійснення підприємницької діяльності майна та коштів фізичних і юридичних осіб;

- самостійне формування програми діяльності, вибір постачальників і споживачів продукції, що виробляється, встановлення цін відповідно до законодавства;

- вільне наймання працівників;

- залучення і використання матеріально-технічних, фінансових, трудових, природних та інших ресурсів, використовувати які законодавство не забороняє і не обмежує;

- вільне розпорядження прибутком, що залишається після сплати обов'язкових платежів, установлених законодавством;

- самостійне здійснення підприємцем-юридичною особою зовнішньоекономічної діяльності, використання підприємцем належної йому частки валютної виручки на свій розсуд.

Підприємництво в Україні здійснюється в будь-яких організаційних формах на розсуд підприємця. Порядок створення, діяльності, реорганізації та ліквідації окремих організаційних форм підприємництва визначається відповідними законодавчими актами України. Якщо такий порядок спеціальним законодавством не встановлено, то підприємець керується Законом України «Про підприємництво» і своїм статутом. Цим законом регулюються також відносини, пов'язані зі здійсненням підприємницької діяльності. Для здійснення підприємницької діяльності підприємець має право укладати договори 3 громадянами про використання їхньої праці. При укладанні трудового договору (контракту, угоди) підприємець зобов'язаний забезпечити умови та охорону праці, оплату іiї не нижче встановленого в країні мінімального рівня, а також інші соціальні гарантії, у тому числі соціальне і медичне страхування та соціальне забезпечення. [3.c.47].

Вивчаючи питання підприємництва як суспільного явища в умовах ринку нами вбачається один незаперечний факт того, що підприємець діє заради привласнення прибутку. Однак для того щоб одержати прибуток підприємцю необхідно здійснити певні витрати, а це сировина, матеріали та інші необхідні ресурси в залежності від виду діяльності. Та крім того до переліку витрат, крім сировини, матеріалів входить така складова витрат як оплата праці, а як відомо підприємець завжди прагне до економії всіх ресурсів та в тому числі, як свідчать окремі випадки, намагається економити й на зарплаті найманих працівників. Тому вивчаючи дане питання нами зосереджується особлива увага на тому, щоб головна мета підприємця до власного збагачення не суперечила суспільним інтересам, а це зокрема дотримання вимог щодо встановленої 
державою мінімальної заробітної плати, забезпечення необхідних умов праці працюючим, турбуючись при цьому за чисте навколишнє середовище, а також забезпечувати якість виробленої продукції чи послуг. Отже стратегією підприємництва ми бачимо таку, де програма дій яка забезпечує здійснення місії головної мети підприємницької діяльності на ринку товарів і послуг, тобто досягнення іï бажаних цілей, а також втілення в життя таких заходів, де невідємною частиною діяльності підприємця в умовах ринку $є$ його участь у розв'язанні соціальних і економічних проблем суспільства. . [10. с. 177]. Адже сьогодні є незаперечним той факт, що ринкова економіка сприяє розвитку підприємництва, створюючи при цьому рівні умови як для приватних так і суспільних інтересів, а також як відомо, що не допускається втручання державних органів у господарську діяльність підприємців, якщо вона не порушує передбачених законодавством України прав державних органів щодо здійснення контролю за діяльністю підприємців. Тобто сьогодні підприємницька діяльність має всі можливості проявляти себе для досягнення конкурентних переваг на ринку. Адже ринок поряд 3 тим, що дає можливість для необмеженого поля прикладання зусиль підприємницької діяльності, чекає інновацій та різноманітних дій, щоб забезпечити різноманітні людські потреби. За позитивне хочемо показати те, що сучасне підприємництво, беручи до уваги той факт, що ринкове середовище постійно змінюється, в своїй діяльності практикує застосування стратегічного планування, яке поєднує методи довгострокового та маркетингового планування, яке спрямоване на збільшення кількості нових продуктів та визначення місця того чи іншого підприємства в майбутньому. При цьому сама процедура стратегії підприємництва в практичній площині передбачає певний ряд етапів, де основним змістом яких $\epsilon$ насамперед глибокий аналіз фінансового забезпечення, тобто бачення перспективних джерел необхідних надходжень для започаткованого підприємництва, а також пошук та формування нових можливостей, планування ризиків та організацію контролю. Сьогодні підприємництво є одним із різновидів творчої, пошукової, ризикової соціальної діяльності, що по суті формує рушійну силу суспільного прогресу. Тому підприємництво в більшості країн світу з ринковою економікою вважається одним із найпрестижніших. Адже саме цей вид діяльності у відповідних умовах найкращим чином виявляє людську суть, допомагає прояву працівника як особистості. Підприємництву властивий більш індивідуальний характер, високий ступінь стимулювання співробітників, що призводить до більш повної реалізації потенціалу кожного з них. При цьому здійснюючи самостійну підприємницьку діяльність, створюються умови для збільшення робочих місць, що $є$ досить важливим, крім цього працівник значно зростає як людина: він росте і професійно і інтелектуально і це має цілком реальні позитивні наслідки для всього суспільства. Історія доводить, що для того щоб підняти економіку, інші сфери буття до високого рівня розвитку, можливо переважно лише через прояв членами цього суспільства їх господарської ініціативи. [9.c.87]. Адже розвиток підприємництва передбачає раціоналізацію економіки, підвищення конкурентоспроможності, позбавлення від баласту ресурсів, що не використовуються або погано експлуатуються та більш повну реалізацію основного потенціалу суспільства-людини.

У сучасній економіці підприємницька діяльність за своїми формами є досить різноманітна, де кожна 3 них виконує відповідно свої функції. 3 найбільш поширених іiі форм, це зокрема такі як виробниче, комерційне та посередницьке підприємництво. Функція виробничого підприємництва спрямоване головним чином на випуск товарів чи надання послуг. Щодо комерційного підприємництва то воно передбачає проведення торговельних та обмінних операцій з купівлі-продажу товарів та послуг. При цьому об'єктами продажу є гроші, валюта, цінні папери. Посередницьке ж підприємництво призначене для налагодження зв'язків між виробниками та споживачами. Такі підприємницькі фірми надають інформаційні, консультативні та інші послуги що є необхідними атрибутами ринкової економіки. В останні роки створюються і нові 
суб'єкти підприємництва такі як комерційні банки, фондові біржі, інвестиційні та страхові компанії. [2.c.163].

Під час підготовки даної публікації нами вивчалися питання щодо підприємництва у Волинській області, а також іх значимість і роль для суспільства. Як відомо і свідчить практика підприємець як правило забезпечує кращі результати своєї діяльності, тому , що він $є$ кваліфікованим спеціалістом, який добре знає свою справу. Підприємець більш мобільний у своїй справі і може краще інших працювати на споживача, а також, що $є$ досить суттєвим, що підприємець використовує наявні ресурси з найбільшою віддачею та вміє долати труднощі. 3 метою покращення роботи в розвитку підприємництва у Волинській області нині діє відповідна програма під назвою «Про регіональну програму підтримки малого та середнього підприємництва у Волинській області на 2018-2020 роки». Дана програма прийнята Волинською обласною радою від 26.09.2018 № 21/5 відповідно до ст.5,9., Закону України «Про розвиток та державну підтримку малого та середнього підприємництва в Україні». Згадана програма передбачає мобілізацію роботи по покращенню ефективної підтримки малого та середнього підприємництва, здійснення політики зайнятості населення, створення сприятливих умов по збільшенню робочих місць для працевлаштування, зростання заробітної плати, а також передбачається здійснення відшкодування 3 обласного бюджету відсоткових ставок за кредитами, залученими суб'єктами малого і середнього бізнесу для реалізації інвестиційних бізнеспланів, які реалізуються у пріоритетних галузях економіки області. Для підтримки підприємництва в області функціонують 67 об'єктів інфраструктури підприємництва, в тому числі 4 фонди підтримки підприємництва. Як свідчать статистичні дані, які нами вивчалися, що станом на 01.01.2019 на обліку в органах ДФС Волинської області перебувало 59265 юридичних та фізичних осіб - підприємців, тоді коли станом на 01.01.2018 на обліку в органах ДФС Волинської області перебувало 58124 юридичних та фізичних осіб - підприємців, такі дані свідчать про кількісне зростання зайнятих у підприємництві. Наводимо також позитивну динаміку даних щодо сплати податків суб' єктами підприємницької діяльності, де зокрема станом на 01.01.2019 на податковому обліку перебувало 1806 юридичних осіб - платників єдиного податку 3-ї групи (на 111 осіб більше, ніж на 01.01.2018), які сплатили 64 млн. грн.. єдиного податку, та 25462 фізичних осіб платників єдиного податку (на 1371 осіб більше, ніж на 01.01.2018), які сплатили 343,1 млн. гривень. Узагальнюючи наші дослідження при підготовці даної публікації нами пропонується поряд 3 позитивним у підприємницькій діяльності, ширше застосовувати питання навчання та обміну досвідом, адже за свідченням науковців про те, що із немалої кількості бажаючих до підприємництва лише 5 - 7\% населення мають власні необхідні риси для успішної підприємницької діяльності, тобто вбачається основна суть в тому щоб дати можливість початківцям, новим, молодим та амбіційним підприємцям набувати навичок і знань у досвідчених підприємців, які володіють такими здібностями, що дасть можливість значно розширити поле діяльності підприємництва і забезпечення бажаних результатів.

Висновки. В даній статті окреслено суть підприємництва та умови його існування, а саме дослідження того, що підприємництво це ініціативна діяльність, спрямована на пошук варіантів найбільш ефективного використання ресурсів 3 метою одержання прибутку. Охарактеризовано поняття підприємництва як економічну категорію, а також наведені приклади існуючих суб'єктів підприємництва. Відображена роль і значимість підприємництва в розвитку соціальних та економічних явищах в умовах ринку.

Список використаних джерел:

1.Закон України «Про підприємництво» //Галицькі контракти.- 1998.№8.- с.129-159.

2.Загальна економіка: Підручник / За ред. І.Ф.Радіонової - К.- Подільський, 2002.

3. Бойчик І. М., Харів П. С., Хопчпн М. І., Піча Ю. В. Економіка підприємства - К.: "Каравела"; Львів: "Новий світ 2000", 2001. - 298 c.

4. Грузинов В. П., Грибов В. Д. Экономика предприятия: Учебное пособие. - М.: Финансы и статистика, 1998. 
5. Економіка підприємства: Підручник / За заг. ред. С. Ф. Покропивного - Вид 2-ге. - К.: КНЕУ, 2000.

6. Економіка підприємства. Збірник практичних задачі і конкретних ситуацій: Навч. Посібник. / За ред. С. Ф. Покропивного. - К.: КНЕУ, 1999.

7. Економіка підприємства: Навч. -метод. посібник для самостійного вивчення дисциплін / О. Г. Швиданенко та інші

- К.: КНЕУ, 2000.

8. Економіка підприємства: Структурно-логічний навч. посібник/ За ред. С. Ф. Покропивного. - К.: КНЕУ, 2001. - 457 c.

9. Мадзігон В.В. Теорія попиту і пропозиції $\quad$ в $\quad$ підприємницькій $\quad$ діяльності $\quad$ в $\quad$ реаліях ринкової економіки на товари і послуги. // Молодь і ринок. - 2011. - №2(73). - С. 41 - 46.

10. Мадзігон В.М. Підприємництво: причини виникнення i форми існування, підготовка мол оді до підприємницької діяльності// Актуальні проблеми економіки. - 2010. - №7(109). - С. 3 - 12.

11.Я.О. Орищак М.І. Стебло Основи економіки. м. Тернопіль, 1998р. С - 110.

Рецензент д.е.н., професор Вахович I.М.

УДК 620.9(477):33.021.8

Ліщук В.І., к.е.н., доцент

Східноєвропейський національний університет імені Лесі Українки

Ліщук М.С., к.с.-Г.н., доцент

Московчук А.Т., к.е.н., доцент

Луцький національний технічний університет

\section{РЕФОРМУВАННЯ РИНКУ ЕЛЕКТРОЕНЕРГІЇ В УКРАЇНІ: СТАН, РИЗИКИ ТА ПЕРСПЕКТИВИ}

У статті розглянуто проблему реформування електроенергетичного ринку України та перспективи його інтегрування у європейський енергетичний простір. Здійснено аналіз етапів реформування ринків електроенергії країн Європейського Союзу 3 точки зору завдань і проблем, що виникали. Охарактеризовано стан реформування ринку в Україні та основні ризики. Окреслено основні заходи, що сприятимуть підвищенню ефективності реформ.

Ключові слова: оптовий ринок електроенергії, балансуючий ринок, внутрішньодобовий ринок, ринок «на добу вперед», ризик, «зелений» тариф, анбандлінг.

Lishchuk V., Lishchuk M., Moskovchuk A.

\section{THE ELECTRICITY MARKET IN UKRAINE REFORMATION: STATE, RISKS AND PERSPECTIVES}

The article deals with the reformation problem of Ukrainian electricity market and the prospects for its integration into the European energy space. The analysis of the stages of reforming the electricity markets of the European Union countries their tasks and problems that have arisen has been analyzed. The state of market reform in Ukraine and the main risks are described. The main measures that will promote the effectiveness of reforms are outlined.

Key words: wholesale electricity market, balancing market, internal market, «day ahead» market, risk, «green» tariff, unbundling.

Лищук В. И., Лищук М. Е., Московчук А. Т.

\section{РЕФОРМИРОВАНИЕ РЫНКУ ЭЛЕКТРОЭНЕРГИИ В УКРАИНЕ: СОСТОЯНИЕ, РИСКИ И ПЕРСПЕКТИВЫ}

В статье рассмотрена проблема реформирования электроэнергетического рынка Украины и перспективы его интегрирования в европейское энергетическое пространство. Осуществлен анализ этапов реформирования рынков электроэнергии стран Европейского Союза с точки зрения задач и проблем, которые возникали. Охарактеризовано состояние реформирования рынка в Украине и основные риски. Определены основные мероприятия, способствующие повышению эффективности реформ. 